\title{
Students' Perception towards Online-Class during COVID-19 Pandemic
}

\author{
Dipak Mahat (PhD Scholar) \\ Researcher, Nepal Philosophical Research Center, Kathmandu \\ Email: dipakmahatdm2047@gmail.com
}

Received: November 12, 2020; Revised \& Accepted: January 6, 2021; Published: February 18, 2021 (C) Copyright: Mahat (2021).

\begin{abstract}
Effect of COVID-19 on educational institution has interrupted the traditional method of teaching and learning which ultimately created the demand of online class. In this background, study aim was to find out the perception of students towards online-class during COVID-19 pandemic. The study was based on descriptive research design. The study was carried out by using the structured questionnaire survey, and self-administered online Google firm was developed to collect the data. The data were collected from 109 students of two colleges; one public and one private college. The reliability test of collected data was checked by calculating the Cronbach's Alpha value. Frequency, percentage, and mean was used to analyze the data. Finding of the study revealed that $81.7 \%$ students adopted online class first time in their learning career. However, majority of respondents felt confident to use online-class function and adopt content. Similarly, 58.1\% respondents reported that they faced the technical problem during Online-class, more than 59\% respondents believed that online class was one of the easiest platforms to share the knowledge and collect the required information. Most of the respondents intended to use online-class platform to enhance their learning and communication skill. One of the main benefits of online class was that it has saved the students from risk of transmission of COVID-19 and contributed to the regularity of teaching and learning of college. Considering such critical time, colleges should provide the adequate knowledge of Information Technology (IT) to their students and teachers to enhance their technical skill.
\end{abstract}

Keywords: Covid-19, Online-class, pandemic, perception, students.

\section{INTRODUCTION}

The COVID-19 pandemic affects everyone and everywhere. Threat of the pandemic as a result of COVID-19 is causing a series of transformations in the different spheres of social, political, labor, and economic life (Espino-Díaz, Fernandez-Caminero, Hernandez-Lloret, Gonzalez-Gonzalez, \& Alvarez-Castillo, 2020). The ongoing COVID-19 pandemic severely damaged the world's most developed countries and is becoming a major threat for low- and middle-income countries (Lone \& Ahmad, 2020). Different countries have established different 
forms of quarantine, interrupting numerous ordinary routines and affecting work, free movement, trade, and, in particular, education (Alzahrani, Alrusayes, \& Aldossary, 2020).The COVID-19 pandemic has created the largest disruption of education systems in history, affecting nearly 1.6 billion learners in more than 190 countries and all continents ( United Nation, 2020).

The education sector in Nepal and across the world has been one of the hardest hits owing to the pandemic which has deeply affected learning outcomes for children. Nepal is still combating the COVID-19 pandemic in the world, like other nations. The Government of Nepal implemented a lockdown starting on March 24 to close schools, colleges, universities including all Educational institution (Sherchand, 2020). Because of the compulsory closure of schools and universities for a considerable period of time, the education system has changed dramatically, with the distinctive rise of e-learning whereby teaching and learning is undertaken remotely and on digital platforms (Dawadi, Simkhada, \& Giri, 2020). Many universities and colleges worldwide suspended classroom teaching due to the novel corona virus pandemic and switched to online teaching (Mahdy, 2020). In Nepal Online class has been a reality since COVID-19 pandemic and served as an alternative educational tool (Gupta, Shrestha, Shrestha, Acharya, \& Pandey, 2020). Many education institutions shifted to Online class through Zoom, Microsoft Team, Google meet, Google Classroom. In the context of Nepal, the practice of online classes is new to many colleges (teachers and students) and also there is no good access to electricity and internet service in most parts of the country (Subedi, Nayaju, Subedi, Shah, \& Shah, 2020). In this scenario it is importance to understanding of how students perceive and react to the practice of Online -Class along with how to apply these approaches most effectively to enhance effectiveness of Online-Class.

There are number of researches undertaken to identify the impact of COVID-19 on education sectors. Some the studies conducted in Nepalese context are: 'Impact of COVID-19 on the Education Sector in Nepal - Challenges and Coping Strategies', conducted by Gupta et al. (2020), next, 'Perception of BDS students of Kathmandu University on online learning during COVID-19 pandemic', Conducted Dawadi et.al. (2020), 'Effects of COVID-19 Pandemic on Medical Education in Nepal', conducted by Jeevan Bahadur Sherchand (2020). However, none of these studies provides a clear picture of student's perception towards Online-Class during COVID-19 Pandemic with reference to management students. Thus, this study attempts to fill this gap.

\section{RESEARCH OBJECTIVE}

The main objective of this study is to analyze the students' perceptions towards the Online-Class during Covid-19 lockdown period.

\section{MATERIALS \& METHODS}

The present study is descriptive in nature (Mahat \& Mathema, 2018). This study was conducted in the public (Shanker Dev Campus) and Private (Times International Collage) collage of Kathmandu District. The study collected the primary data to solve the research 
International Research Journal of MMC (IRJMMC)

Vol. 2 Issue 1 (February, 2021)

ISSN 2717-4999 (Online)

2717-4980 (Print)

problem. However, secondary data were also used to discuss and justify the finding of this study. Management students studying under Tribhuvan University who were willing to participate, attending online-class were the primary respondents of this study. The study had used the structured survey questionnaire having with five-point Likert scale. Data was collected from 109 students of selected college. Self-administered online Google firm-based survey questionnaire was sent via email, Messenger, Microsoft team to the students. Frequency, Percentage, Mean, Standard deviation were used to analyze the data by using the SPSS (20 versions). The researcher used Cronbach's Alpha to test the reliability of data because it is one of the important tools used to check the internal consistency of data. The Cronbach's alpha value of data was 0.908 which indicates the excellent quality of data.

\section{RESULTS \& DISCUSSIONS}

The study had examined the demographic information of Students, like Gender, Age, Education, Experience of Online-Class, IT skill. The data presented in the Table 1 shows that majority of respondents were Male (53.2\%) and 46.8\% were Female.

Table1: Demographic Information of Respondent

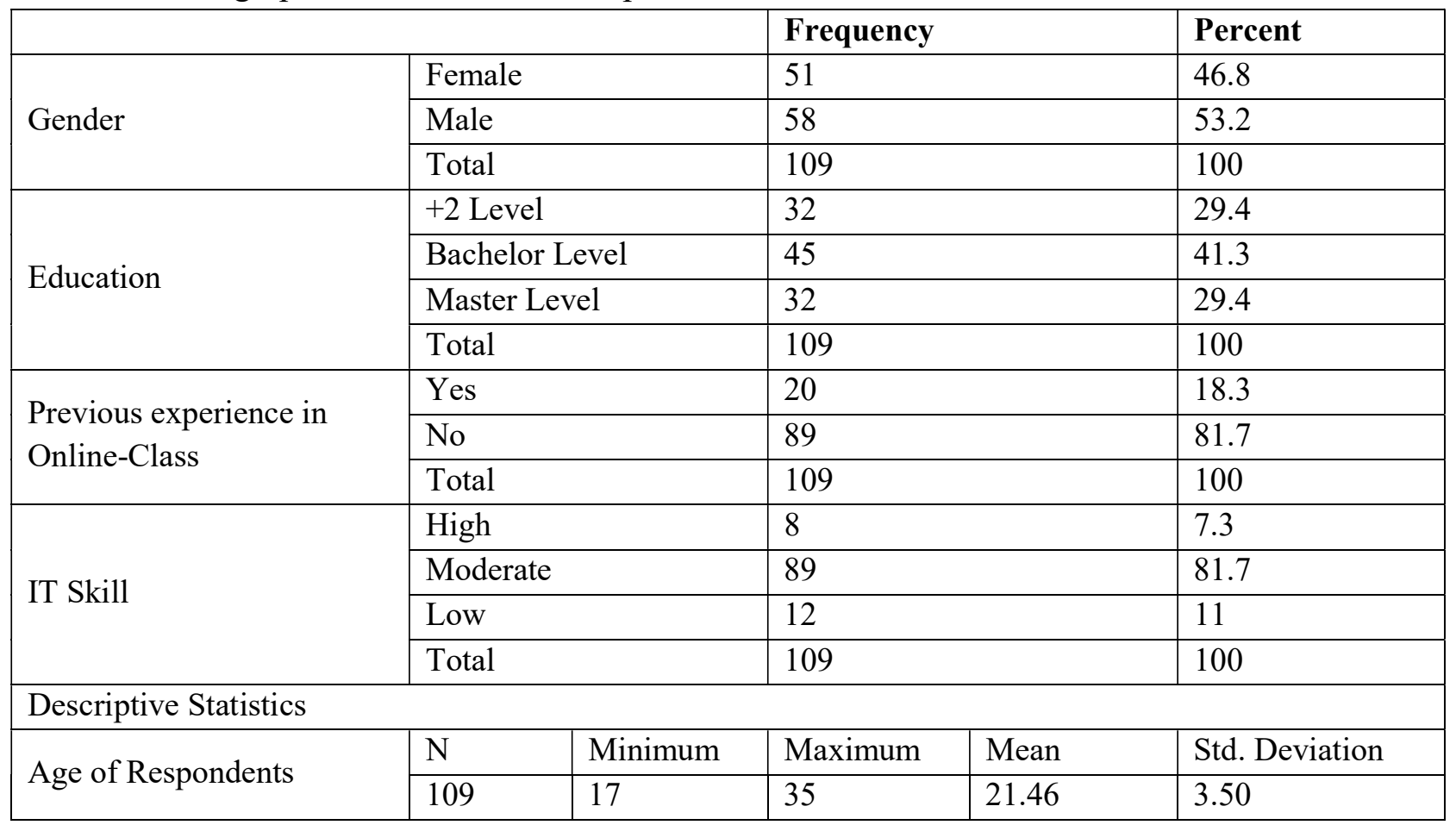

Source: Field Survey, 2021

Education level of respondents as mentioned in above Table 1 which shows that in total $32(29.4 \%)$ respondents belong to +2 level, 45 (41.3\%) respondents belong to Bachelor level, similarly 32(29.4\%) respondents belong to Master Level. Thus, this study shows that the highest number of respondents belong to Bachelor, whereas +2 level and Master level have equal number of respondents. 
International Research Journal of MMC (IRJMMC)

Vol. 2

Issue 1 (February, 2021)

ISSN 2717-4999 (Online)

2717-4980 (Print)

In case of experience in Online Class, the data shows that 20(18.3\%) respondents had previous experience in online class whereas $89(81.7 \%)$ respondents reported that they had no previous experience of online class. Likewise, the study also explored IT skill of students. Out of 109 respondents, $8(7.3 \%)$ had high skill, $89(81.7 \%)$ respondents had moderate skill, and 12(11\%) respondents had low skill. The study found that the age of students was minimum 17 years to maximum 35 year. The average age of students was 21.4679 years.

\section{Usefulness of Online Class}

Increase in the COVID pandemic worldwide has also added to the importance of online classes (Kula \& Nayak, 2020). Although e-learning offers the convenience, flexibility and ability to access classes remotely on the participant's own time, participants may feel isolated. This is because online learning is an individual act of joint activity, which may give the feeling that they are acting entirely on their own (Fatonia, et al., 2020). The perception of students on usefulness of online class was presented in below table.

Data was collected from the respondents by asking the question that studying through online mode provide them flexibility time to learner, data shows that there was minimum percentage $(3.7 \%)$ of respondents who responded on 'strongly disagree' with the statement. Apart from this, 17.4\% of respondents disagreed, 31.2\% of respondents had neutral response with the statement. Similarly, $43.1 \%$ of respondents replied 'Agree' with the statement and 4.6\% marked on 'strongly agree'. On aggregate, more than $47 \%$ of respondents agreed that online class has provided flexibility time to learn whereas $21.1 \%$ respondents were disagreed with the same statement. The result indicates that comparatively higher number of students were happy with the online class which provided flexible time to learn.

Table 2: Students perception on usefulness of Online-class

\begin{tabular}{|l|l|l|l|l|l|l|}
\hline \multirow{2}{*}{ Statements } & $\begin{array}{l}\text { Strongly } \\
\text { Disagree }\end{array}$ & Disagree & Neutral & Agree & $\begin{array}{l}\text { Strongly } \\
\text { Agree }\end{array}$ \\
\hline Studying through online mode provides & Count & 4 & 19 & 34 & 47 & 5 \\
\cline { 2 - 7 } flexibility time to the learner & $\%$ & 3.7 & 17.4 & 31.2 & 43.1 & 4.6 \\
\hline $\begin{array}{l}\text { Online-Class can enable students to study } \\
\text { irrespective of where they are located. }\end{array}$ & Count & 7 & 15 & 12 & 45 & 30 \\
\cline { 2 - 8 } & $\%$ & 6.4 & 13.8 & 11 & 41.3 & 27.5 \\
\hline $\begin{array}{l}\text { There are technologies available to take tests } \\
\text { and submit assignments electronically. }\end{array}$ & Count & 2 & 6 & 11 & 63 & 27 \\
\cline { 2 - 8 } & $\%$ & 1.8 & 5.5 & 10.1 & 57.8 & 24.8 \\
\hline \multirow{2}{*}{$\begin{array}{l}\text { There are electronic tools available to } \\
\text { communicate with lecturer. }\end{array}$} & Count & 4 & 10 & 11 & 63 & 21 \\
\cline { 2 - 8 } & $\%$ & 3.7 & 9.2 & 10.1 & 57.8 & 19.3 \\
\hline $\begin{array}{l}\text { Students have no technical problems at the } \\
\text { time of Online-Class. }\end{array}$ & Count & 37 & 46 & 17 & 6 & 3 \\
\cline { 2 - 7 } & $\%$ & 33.9 & 24.2 & 15.6 & 5.5 & 2.8 \\
\hline
\end{tabular}

Source: Field Survey, 2021

During the time of questionnaires survey, respondents were asked if Online-Class can enable students to study irrespective of where they are locating or not. It can be interpreted that, 
about $6.4 \%$ of respondents Strongly disagreed followed by $13.8 \%$ disagreed with the statement. About $11 \%$ respondent had neutral response and remaining $41.3 \%$ agreed followed by $27.5 \%$ respondents strongly agreed with the statement. In all, most of the respondents $44.8 \%$ agreed with the statement that online class was one of the medium for them to study from their chosen location and only $20.2 \%$ respondents disagreed with the statement.

Respondents were asked that there is technology available to take tests and submit assignments electronically due to online class. In this statement, in total $57.8 \%$ of respondents agreed while $24.8 \%$ respondents strongly agreed and $10.1 \%$ respondent gave neutral response, whereas $5.5 \%$ disagreed followed by $1.8 \%$ strongly disagreed with the statements. Researcher had divided the respondents into two categories: Agree and Disagree. It was found that, majority $(82.6 \%)$ of respondents agreed followed by $7.3 \%$ disagreed and rest had neutral response. The result shows that majority of students agreed that there was easy to submit assignment and to attend in the exam through online technology.

Similarly, in the question about the availability of electronic tools to communicate with lecturer, in the response of this question, in total $57.8 \%$ of respondents agreed while $19.3 \%$ respondents strongly agreed and $10.1 \%$ respondent's response neutral answer whereas $9.2 \%$ disagreed followed by $3.7 \%$ strongly disagreed with the statements. Researcher had divided the respondents into two categories: Agree and Disagree. It was found that, majority $(77.1 \%)$ of respondents agreed followed by only $12.9 \%$ disagreed which indicates that there was easy availability of electronic tools to communicate with lecturer.

Similarly, researcher asked that students had no technical problems at the time of OnlineClass. In this question, in total $33.9 \%$ of respondents strongly disagreed while $24.2 \%$ respondents disagreed and $15.6 \%$ respondent had neutral response whereas $5.5 \%$ agreed followed by $2.8 \%$ strongly agreed with the statements. In totality, it was found that, majority $(58.1 \%)$ of respondents disagreed followed by $8.3 \%$ agreed which indicates that most of the students face technical problems like difficulty in connection, electricity problem, weak internet, difficulty to submit assignment on time and so on.

\section{Self-Efficacy of Using Online-Class}

Self-efficacy beliefs determine how people might feel, think, be motivated and therefore how they act and behave (Alqurashi, 2016). Student self-efficacy seems particularly important in challenging learning environments (Peechapol, Na-Songkhla, Sujiva, \& Luangsodsai, 2018). So, the study had also asked to the students about their perception on self-efficacy of using online class. 
International Research Journal of MMC (IRJMMC)

Vol. 2

Issue 1 (February, 2021)

ISSN 2717-4999 (Online)

2717-4980 (Print)

Table 3: Students perception on self-efficacy of using Online-class

\begin{tabular}{|l|l|l|l|l|l|l|}
\hline \multicolumn{2}{|l|}{ Statements } & $\begin{array}{l}\text { Strongly } \\
\text { Disagree }\end{array}$ & Disagree & Neutral & Agree & $\begin{array}{l}\text { Strongly } \\
\text { Agree }\end{array}$ \\
\hline \multirow{2}{*}{$\begin{array}{l}\text { I feel confident while using online } \\
\text { Class system. }\end{array}$} & Count & 9 & 14 & 43 & 32 & 11 \\
\cline { 2 - 8 } & $\%$ & 8.3 & 12.8 & 39.4 & 29.4 & 10.1 \\
\hline $\begin{array}{l}\text { I feel confident while operating } \\
\text { Online-Class functions. }\end{array}$ & Count & 5 & 20 & 31 & 44 & 9 \\
\cline { 2 - 8 } $\begin{array}{l}\text { I feel confident while using online- } \\
\text { learning content. }\end{array}$ & $\%$ & 4.6 & 18.3 & 28.4 & 40.4 & 8.3 \\
\cline { 2 - 8 } & $\%$ & 6.4 & 18.3 & 29.4 & 43.1 & 2.8 \\
\hline
\end{tabular}

Source: Field Survey, 2021

The study collected the data from the respondents by asking the question that whether they felt confident while using Online class. In total, comparatively higher numbers (39.4\%) of respondent had given neutral response while $29.4 \%$ respondents agreed and $10.1 \%$ respondent responded strongly agree, whereas $12.8 \%$ respondents were disagree followed by $8.3 \%$ were strongly disagree with the statements. Researcher had divided the respondents into two categories: Agree and Disagree by computing the data of same kind. It was found that, $47.8 \%$ of respondents agreed followed by only $21.1 \%$ disagreed; from data it is clear that majority of the students felt confident while using online class whereas next larger numbers $(39.4 \%)$ of respondent's responded neither disagree nor agree.

Respondents were asked that whether they feel confident while operating online class. In this response, in total $40.4 \%$ of respondents agreed followed by $8.3 \%$ strongly agreed while $28.2 \%$ respondent had neutral response whereas $18.3 \%$ respondent responded disagree followed by $4.6 \%$ strongly disagreed with the statements. In total, it was found that, majority (48.7\%) of respondents agreed followed by only $22.9 \%$ disagreed. From the above result of data, it is clear that most of the students were confident to operate online class.

Similarly, students were asked whether they felt confident while using online learning content. In the response of this question, in total $43.1 \%$ of respondents agreed followed by $2.8 \%$ strongly agreed while $29.4 \%$ respondent had neutral response and $18.3 \%$ respondent's response on disagree followed by $6.4 \%$ strongly disagreed with the statements. In total, it was found that, majority (45.9\%) of respondents agreed followed by only $24.7 \%$ disagreed in the response of level of confidentiality while using the online-learning contents. From the result of data, it is clear that most of the students were found confident to using online learning content.

\section{Ease Use of Online-Class}

A previous review study reviewed the 96 peer-reviewed research articles published between 2006 to 2016, and revealed that a majority of studies witnessed an increased reliance on online platforms due to ease of use and availability of online services. For both students and teachers, they felt comfortable to communicate with each other due to fast and efficient connectivity provided by the online communication system (Froment, Javier, \& Rocio, 2017). In 
International Research Journal of MMC (IRJMMC)

Vol. 2

Issue 1 (February, 2021)

ISSN 2717-4999 (Online)

2717-4980 (Print)

this connection, the study also collected data to know the ease use of online class. The data is presented in Table 4.

Table 4: Students perception on ease use of Online-class

\begin{tabular}{|l|l|l|l|l|l|l|}
\hline \multicolumn{2}{|l|}{ Statements } & $\begin{array}{l}\text { Strongly } \\
\text { Disagree }\end{array}$ & Disagree & Neutral & Agree & $\begin{array}{l}\text { Strongly } \\
\text { Agree }\end{array}$ \\
\hline $\begin{array}{l}\text { I believe Online-Class platforms are } \\
\text { user friendly. }\end{array}$ & Count & 10 & 13 & 31 & 48 & 7 \\
\cline { 2 - 8 } & $\%$ & 9.2 & 11.9 & 28.4 & 44 & 6.4 \\
\hline $\begin{array}{l}\text { It would be easy for me to find } \\
\text { necessary information when using an } \\
\text { Online-Class platform. }\end{array}$ & Count & 6 & 12 & 26 & 55 & 10 \\
\cline { 2 - 8 } & $\%$ & 5.5 & 11 & 23.9 & 50.5 & 9.2 \\
\hline $\begin{array}{l}\text { I believe that using Online-Class } \\
\text { service can simplify the-learning } \\
\text { process. }\end{array}$ & Count & 12 & 18 & 27 & 38 & 14 \\
\cline { 2 - 8 } & $\%$ & 11 & 16.5 & 24.8 & 34.9 & 12.8 \\
\hline $\begin{array}{l}\text { The set-up of the online-learning } \\
\text { service is compatible with the way I } \\
\text { learn. }\end{array}$ & Count & 8 & 30 & 32 & 36 & 3 \\
\cline { 2 - 8 } & 7.3 & 27.5 & 29.4 & 33 & 2.8 \\
\hline
\end{tabular}

Source: Field Survey, 2021

During the time of questionnaires survey, respondents were asked "I believe Online-Class platforms are user friendly". It can be interpreted that, about $9.2 \%$ of respondents Strongly disagreed followed by $11.9 \%$ disagreed with the statement. About $28.4 \%$ respondent had neutral response and remaining $44 \%$ agreed followed by $6.4 \%$ respondents strongly agreed with the same statement. In total, most of the respondents (50.4\%) agreed with the statement that online class was user friendly and only $21.1 \%$ respondents disagreed with the statement.

Respondents were also asked that "It would be easy for me to find necessary information when using an Online-Class platform". In this statement, in total 50.5\% of respondents agreed, 9.2\% respondents strongly agreed and $23.9 \%$ respondent gave neutral response, whereas $11 \%$ disagreed followed by $5.5 \%$ strongly disagreed with the statements. Researcher had divided the respondents into two categories: Agree and Disagree by computing the value of agree and disagree. Then, it was found that, majority (59.7\%) of respondents agreed followed by $16.5 \%$ disagreed and rest had neutral response. The result shows that majority of students agreed that online class platform was easy medium to find the necessary information that they want.

Similarly, students were asked that "I believe that using Online-Class service can simplify the-learning process". In the response of this question, in total $34.9 \%$ of respondents agreed followed by $12.8 \%$ strongly agreed while $24.8 \%$ respondent had neutral response and $16.5 \%$ students responded on disagree followed by $11 \%$ strongly disagreed with the statements. In total, it was found that, majority $(47.7 \%)$ of respondents agreed followed by only $27.5 \%$ disagreed. From the result of data, it is clear that most of the students believed that online class had supported to simplify the learning process. 
International Research Journal of MMC (IRJMMC)

Vol. 2

Issue 1 (February, 2021)

ISSN 2717-4999 (Online)

2717-4980 (Print)

Researcher asked that "The set-up of the online-learning service is compatible with the way I learn". In the response of this question, in total 33\% of respondents agreed followed by $2.8 \%$ strongly agreed while $29.4 \%$ respondent had neutral response and $27.5 \%$ respondent's response on disagree followed by $7.8 \%$ strongly disagreed with the statements. In total, it was found that majority (35.8\%) of respondents agreed followed by $34.8 \%$ disagreed. From the result of data, it is clear that most of the students were found compatible in online class.

\section{Behavioral Intention of Using Online-Class-learning}

The outbreak of COVID-19, educational institutions of the affected countries across the globe have stopped taking classes physically and shifted to online mode in order to contain the spread of the virus. Although different forms of online learning have been there in the scenario for quite some time, the current situation of a full-scale online learning can have certain consequences (Khan, Zainuddin, Mahi, \& Arif, 2020). Focusing of this special issue on students' perspectives, it is very necessary to know the behavioral of using online class following table presented.

Data were collected from the respondents by asking the question that "I intend to use online-class to develop my learning habit", data shows that $10.1 \%$ of respondents who responded on 'strongly disagree' with the statement. Apart from this, $17.4 \%$ of respondents disagreed, $19.3 \%$ of respondents had neutral response with the statement. Similarly, $46.8 \%$ of respondents replied 'Agree' with the statement and 9.2\% marked on 'strongly agree'. On aggregate, more than $56 \%$ of respondents agreed that online class has provided flexibility time to learn whereas $24.8 \%$ respondents were found disagree with the same statement. The result indicates that using of Online class developed students learning habit.

Table 5: Students behavioral intention of using Online-class learning

\begin{tabular}{|c|c|c|c|c|c|c|}
\hline \multicolumn{2}{|l|}{ Statements } & $\begin{array}{l}\text { Strongly } \\
\text { Disagree }\end{array}$ & Disagree & Neutral & Agree & $\begin{array}{l}\text { Strongly } \\
\text { Agree }\end{array}$ \\
\hline \multirow{2}{*}{$\begin{array}{l}\text { I intend to use online-class to } \\
\text { develop my learning habit. }\end{array}$} & Count & 11 & 16 & 21 & 51 & 10 \\
\hline & $\%$ & 10.1 & 14.7 & 19.3 & 46.8 & 9.2 \\
\hline \multirow{2}{*}{$\begin{array}{l}\text { I intend to use online-class to saves } \\
\text { time, money and effort. }\end{array}$} & Count & 6 & 15 & 19 & 37 & 32 \\
\hline & $\%$ & 5.5 & 13.8 & 17.4 & 33.9 & 29.4 \\
\hline \multirow{2}{*}{$\begin{array}{l}\text { I intend to use Online-Class as an } \\
\text { autonomous (free) learning tool. }\end{array}$} & Count & 5 & 11 & 26 & 52 & 15 \\
\hline & $\%$ & 4.6 & 10.1 & 23.9 & 47.7 & 13.8 \\
\hline \multirow{2}{*}{$\begin{array}{l}\text { I intend to use Online-Class to } \\
\text { enhance my communication skill. }\end{array}$} & Count & 7 & 11 & 21 & 53 & 17 \\
\hline & $\%$ & 6.4 & 10.1 & 19.3 & 48.6 & 15.6 \\
\hline \multirow{2}{*}{$\begin{array}{l}\text { I intend to use online-class so to } \\
\text { study in comfortable (Homely) } \\
\text { environment. }\end{array}$} & Count & 10 & 10 & 22 & 46 & 21 \\
\hline & $\%$ & 9.2 & 9.2 & 20.2 & 42.2 & 19.3 \\
\hline
\end{tabular}

Source: Field Survey, 2021

The study had collected the data from the respondents by asking the question "I intend to use online-class to saves time, money and effort”. In total, comparatively higher numbers (33.9\%) of respondent had given agreed response while $29.4 \%$ respondents strongly agreed and 
$17.4 \%$ respondent responded neutral response, whereas $13.8 \%$ respondents were disagree followed by $85.5 \%$ were strongly disagree with the statements. Researcher had divided the respondents into two categories: Agree and Disagree by computing the data of same kind. It was found that, $63.3 \%$ of respondents agreed followed by only $19.3 \%$ disagreed; from data it is clear that majority of the students wanted to used online class to save time money and effort.

Respondents were asked "I intend to use Online-Class as an autonomous (free) learning tool". In this response, in total $47.7 \%$ of respondents agreed followed by $13.8 \%$ strongly agreed while $23.9 \%$ respondent had neutral response whereas $10.1 \%$ respondent responded disagree followed by $4.6 \%$ strongly disagreed with the statements. In total, it was found that, majority $(61.5 \%)$ of respondents agreed followed by only $14.7 \%$ disagreed. From the above result of data, it is clear that most of the student's intention was to use online class as an autonomous learning tool.

Similarly, students were asked that "I intend to use Online-Class to enhance my communication skill". In the response of this question, in total $48.6 \%$ of respondents agreed followed by $15.6 \%$ strongly agreed while $19.3 \%$ respondent had neutral response and $10.1 \%$ respondent's response on disagree followed by $6.4 \%$ strongly disagreed with the statements. In total, it was found that, majority $(64.2 \%)$ of respondents agreed followed by only $16.5 \%$ disagreed. From the result of data, it is clear that most of the student's intention was to used online class to enhance communication.

The study collected the data from the respondents by asking the questions "I intend to use online-class so to study in comfortable (Homely) environment". In the response of this question, in total $42.2 \%$ of respondents agreed followed by $19.3 \%$ strongly agreed while $20.2 \%$ respondent had neutral response and $9.2 \%$ respondent's response on disagree followed by $9.2 \%$ strongly disagreed with the statements. In total, it was found that, majority $(61.5 \%)$ of respondents agreed followed by only $18.4 \%$ disagreed. From the result of data, it is clear that most of the student's intention was to use online class for study in comfortable environment.

\section{CONCLUSION OF THE STUDY}

The study has focused on the identification and exploration the perception of college students towards online class. The key findings presented in the below Figure 1 shows that technology available to submit assignment has highest mean value (mean $=3.98$ ) which is closed to the 'Agree' response. Whereas the lowest mean was (mean=2.00) found on the response of 'students have no technical problem during Online Class'. It means students had faced technical problem during online class. 
International Research Journal of MMC (IRJMMC)

Vol. 2

Issue 1 (February, 2021)

ISSN 2717-4999 (Online)

2717-4980 (Print)

Figure 1:Perception of students towards online-class

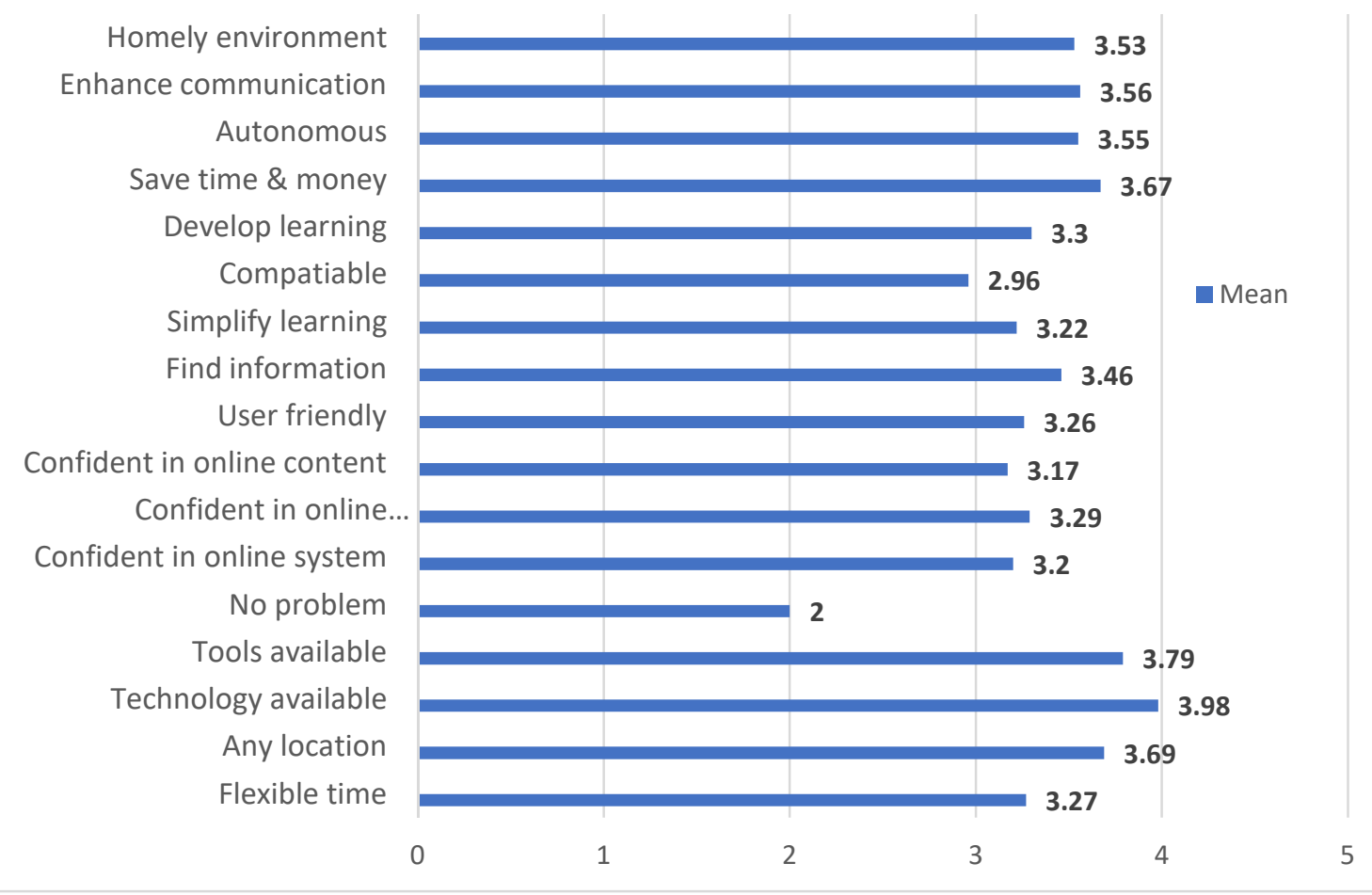

Source: Field Survey, 2021

Findings show that majority of students had adopted online class first time in their learning career but they were enjoying in online class as well as felt comfortable to use online class system, online-class function and adopt content. It was one opportunity also to learn the use of information technology in teaching and learning. Though, majority of respondents reported that e they faced technical problem during Online-class like internet speed issue, issue of electricity, operating Microsoft team and Zoom. Many students believed that online class was one of the easy platforms to share and collect the required information. Most of the respondent intended to use online-class platform to enhance their learning and communication habit. It was observed that majority of students wanted to study in homely environment, and also wanted to use online class as an autonomous tool of learning which saved their time, money and effort during the critical situation of COVID-19. One of the main importances of online class is that it has safe the students from the risk of transmission of COVID-19. The academic sector was bitterly affected by the COVID-19 due the uncertain lockdown, though the practice of online class continued the teaching and learning which has also contributed to reduce the mental stress of COVID-19 among the students.

Based on the above findings and discussion, the study has made the following recommendation for the further work:

1. Campus/College should manage high speed internet in order to reduce technical problem during online-class. 
2. Campus/College should provide Information Technology (IT) training to their students and teachers regarding use of online class in order to enhance their confident.

3. Future researcher can study on the effectiveness of online class in academic achievement of college and school students. The findings can be compared with the effectiveness of physical class.

\section{ACKNOWLEDGEMENT}

I express my gratitude to the all students of private and public campuses. Besides that, I like to thank Dr. Tej Bahadur Karki, Advocate Deepak Raj Kandel and Basanta Prashad Bohara for their guidance and support during my research work. I also like to give my thanks to the Times International Collage and Shanker Dev Campus for their valuable support.

\section{REFERENCES}

Alqurashi, E. (2016). Self-efficacy in online learning environments: A literature review. Contemporary Issues in Education Research, 45.

Alzahrani, S. B., Alrusayes, A. A., \& Aldossary, M. S. (2020). Impact of COVID-19 pandemic on dental education, research, and students. International Journal of Health Sciences and Research, 207.

Dawadi, S., Simkhada, P., \& Giri, R. (2020). Impact of COVID-19 on the education sector in Nepal - Challenges and coping strategies. doi:10.31124/advance.12344336.v1

Espino-Díaz, L., Fernandez-Caminero, G., Hernandez-Lloret, C.-M., Gonzalez-Gonzalez, H., \& Alvarez-Castillo, J.-L. (2020). Analyzing the impact of COVID-19 on Eeducation professionals. Toward a paradigm shift: ICT and neuroeducation as a Bbinomial of Aaction. Sustainability, 2-10.

Fatonia, Arifiatib, N., Nurkhayati, E., Nurdiawati, E., Fidziah, Pamungkas, G., . . Azizi, E. (2020). University students online learning system during Covid-19 pandemic: Advantages, constraints and Ssolutions. A Multifaceted Review Journal in the Field of Pharmacy, 574.

Froment, F., Javier, A., \& Rocio, M. (2017). The use of social networks as a communication tool between teachers and students: A literature review. The Turkish Online Journal of Educational Technology, 126-144.

Gupta, A., Shrestha, R. M., Shrestha, S., Acharya, A., \& Pandey, N. (2020). Perception of BDS students of Kathmandu university on online learning during COVID-19 pandemic. Orthodontic Journal of Nepal, 27.

Khan, S. A., Zainuddin, M., Mahi, M., \& Arif, I. (2020). Behavioral intention to use online learning during COVID-19: An analysis of the technology acceptance model. International Conference on Innovative Methods of Teaching and Technological Advancements in Higher Education, (p. 3). 
Kula, A., \& Nayak, A. (2020). A study on perception of teachers and students toward online classes in Dakshina Kannada and Udupi District. Asian Association of Open Universities Journal, 286.

Lone, S. A., \& Ahmad, A. (2020). COVID-19 pandemic - an African perspective. emerging microbes \& infections. doi:10.1080/22221751.2020.1775132

Mahat, D., \& Mathema, S. (2018). Gender prespective on compensation of health institutionin Ramechhap district of Nepal. Nepal Journal of Multidisciplinary Research, 31.

Mahdy, M. A. (2020). The Impact of COVID-19 pandemic on the academic performance of veterinary medical students. doi:https://doi.org/10.3389/fvets.2020.594261

Peechapol, C., Na-Songkhla, J., Sujiva, S., \& Luangsodsai, A. (2018). An exploration of factors influencing self-efficacy in online learning: A systematic review. International Journal of Emerging Technologies in Learning, 64-65.

Sherchand, J. B. (2020). Effects of COVID-19 pandemic on medical education in Nepal. $M E D$ PHOENIX: An Official Journal of NMC, 86.

Subedi, S., Nayaju, S., Subedi, S., Shah, S. K., \& Shah, J. M. (2020). Impact of E-learning during COVID-19 pandemic among nursing students and teachers of Nepal. International Journal of Science and Healthcare Research, 68.

United Nation. (2020). Policy brief: Education during COVID-19 and beyond. Retrieved from https://www.un.org/development/desa/dspd/wpcontent/uploads/sites/22/2020/08/sg_policy_brief_covid19 and_education_august_2020.p 